\section{Yellowing of Broccoli in Storage Is Reduced by 1-Methylcyclopropene}

\author{
Xuetong Fan ${ }^{1}$ and James P. Mattheis \\ Tree Fruit Research Laboratory, Agricultural Research Service, U.S. \\ Department of Agriculture, Wenatchee, WA 98801
}

Additional index words. Brassica oleracea, ethylene, MCP, respiration

\begin{abstract}
Broccoli (Brassica oleracea L. var. italica Plen) was held for 12 days at $10{ }^{\circ} \mathrm{C}$ in air or in ethylene $\left(1 \mu L \cdot L^{-1}\right)$, with or without prior exposure to $\operatorname{MCP}\left(1 \mu L \cdot L^{-1}\right)$ for 12 hours. In a second experiment, the effects of concentration of $\mathrm{MCP}$, prior to exposure to ethylene, were evaluated. Treatment with MCP reduced whereas exposure to ethylene stimulated respiration and yellowing. Treatment with MCP before continuous exposure to ethylene negated the effects of ethylene. The inhibitory effect of MCP on respiration of broccoli exposed to $1 \mu \mathrm{L} \cdot \mathrm{L}^{-1}$ ethylene was concentration-dependent, while the effect on yellowing was not. The results indicate that the yellowing of broccoli is mediated by ethylene action, and that MCP treatment inhibits yellowing and reduces respiration, even when broccoli is exposed to ethylene. Chemical name used: 1-methylcyclopropene (MCP).
\end{abstract}

Broccoli is a floral vegetable that senesces rapidly after harvest, with senescence primarily expressed as softening and yellowing of the florets and leaves (Hardenburg et al., 1986). The broccoli respiration rate after harvest is high (Hardenburg et al., 1986), and rapid cooling, particularly the use of hydrocooling, is essential to slow deterioration during storage, transport and marketing (Brennan and Shewfelt, 1989, Gillies and Toivonen, 1995). When broccoli is stored at $0{ }^{\circ} \mathrm{C}$ with $95 \%$ relative humidity, quality can be maintained for 2 to 4 weeks (Ryall and Lipton, 1972); however, higher temperatures may occur during transport and marketing. Controlled or modified atmospheres of $0.5-2$ $\mathrm{kPa} \mathrm{O}_{2}$ and 5-10 $\mathrm{kPa} \mathrm{CO}_{2}$ also slow softening and development of yellowing (Bastrash et al., 1993; Izumi et al., 1996, Makhlouf et al., 1989); however, tolerance to these atmospheres is temperature-sensitive and offflavors may develop under anaerobic conditions (Forney et al., 1991).

Yellowing of broccoli is associated with chlorophyll degradation and increased xanthophyll content (Tian et al., 1994; Wang, 1977; Yamaguchi and Watada, 1998). Treating broccoli with exogenous ethylene or propylene promotes yellowing (Borochov and Woodson, 1989; Tian, et al., 1994). Aminoethoxyvinylglycine (AVG), an inhibitor of ethylene synthesis, delays chlorophyll

Received for publication 22 Mar. 1999. Accepted for publication 25 Jan. 2000. We thank David Buchanan and Janie Gausman for technical assistance and Floralife, Walterboro, S.C., for providing Ethylbloc. Mention of a trademark, proprietary product, or vendor does not constitute a guarantee or warranty of the product by the U.S. Dept. of Agriculture and does not imply its approval to the exclusion of other products or vendors that also may be suitable. The cost of publishing this paper was defrayed in part by the payment of page charges. Under postal regulations, this paper therefore must be hereby marked advertisement solely to indicate this fact. ${ }^{1}$ Current address: USDA, ARS, ERRC, 600 E. Mermaid Lane, Wyndmoor, PA 19038. loss and yellowing of broccoli (Wang, 1977) as does application of cytokinins (Batal et al., 1982). The ethylene action inhibitor MCP (Sisler and Serek, 1997), also inhibits flower (Serek et al., 1994; Sisler et al., 1996) and fruit (Abdi et al., 1998; Fan and Mattheis, 1999; Golding et al., 1998) senescence, and treatment of broccoli with MCP reduces yellowing and development of decay ( $\mathrm{Ku}$ and Wills, 1999). Ethylene and/or high temperature storage promote senescence of broccoli florets; therefore, inhibition of ethylene action by MCP provides a means to slow development of yellowing at higher than optimum storage temperatures. The present study provides further information regarding broccoli responses to MCP treatment including reduction in rates of respiration and yellowing during posttreatment storage in air or in ethylene-containing atmospheres.

\section{Materials and Methods}

'Windsor' broccoli harvested from a local farm was used within $6 \mathrm{~h}$ of harvest or stored at $0{ }^{\circ} \mathrm{C}$ prior to treatment. Branchlets were prepared from the whole head, and were surfacesterilized in a $0.01 \%(\mathrm{w} / \mathrm{v}) \mathrm{NaOCl}$ solution for 2 min prior to rinsing twice with distilled water. The branchlets were incubated at $10^{\circ} \mathrm{C}$ for $6 \mathrm{~h}$, then treated with air or $1 \mu \mathrm{L} \cdot \mathrm{L}^{-1} \mathrm{MCP}$ (Floralife, Walterboro, S.C.) in sealed 4-L jars for $12 \mathrm{~h}$ at $10^{\circ} \mathrm{C}$. After the treatment, air, or air with $1 \mu \mathrm{L} \cdot \mathrm{L}^{-1}$ ethylene, flowed continuously through the jars at $5 \mathrm{~L} \cdot \mathrm{h}^{-1}$. The four treatments were: 1) air (control); 2) $1 \mu \mathrm{L} \cdot \mathrm{L}^{-1} \mathrm{MCP}$ for 12 $\mathrm{h}$, then air; 3 ) continuous $1 \mu \mathrm{L} \cdot \mathrm{L}^{-1}$ ethylene; and 4) $1 \mu \mathrm{L} \cdot \mathrm{L}^{-1} \mathrm{MCP}$ for $12 \mathrm{~h}$ followed by continuous $1 \mu \mathrm{L} \cdot \mathrm{L}^{-1}$ ethylene. Light was excluded for the 18 -d posttreatment period. There were five replicates per treatment with $\approx 200 \mathrm{~g}$ broccoli per replicate.

Respiration rate was determined by measuring the $\mathrm{CO}_{2}$ concentration in the outlet flow from each jar. A 1-mL gas sample was withdrawn from the jar outlet, and $\mathrm{CO}_{2}$ in the sample was determined using a HP 5890 gas chromatograph (Hewlett Packard, Avondale, $\mathrm{Pa}$.) equipped with a methanizer (John T. Booker, Austin, Texas) and a 60-cm stainless steel column (2-mm ID) packed with Porapak Q (80/100 mesh). Gas flows for $\mathrm{N}_{2}, \mathrm{H}_{2}$, and air were 65,30 , and $300 \mathrm{~mL} \cdot \mathrm{min}^{-1}$, respectively. Oven, injector, and FID temperatures were 30,50 , and $200{ }^{\circ} \mathrm{C}$, respectively.

Color was measured at the middle point of the branchlet florets using a chromameter (model CR-200; Minolta, Osaka, Japan) set for CIE illuminant $\mathrm{C}$ and fitted with an 8-mm measuring aperture. Hue angle and chroma were used to measure the yellowing and the intensity of yellowing, respectively, of broccoli florets. A total of 25 branchlets were measured (five per replicate).

In the MCP concentration experiment, the broccoli branchlets were treated with $0,0.01$, 0.1 , or $1 \mu \mathrm{L} \cdot \mathrm{L}^{-1} \mathrm{MCP}$ for $12 \mathrm{~h}$ before exposure to continuous $1 \mu \mathrm{L} \cdot \mathrm{L}^{-1}$ ethylene for $12 \mathrm{~d}$.

The experiment was conducted using a completely random design with four treatments and five replicates per treatment. Data was subjected to analysis of variance and the least significant difference procedure (LSD) using SAS vers. 6.12 (SAS Institute, Cary, N.C.). Differences between any two treatments larger than the sum of two standard deviations were always significant (LSD, $P \leq 0.05$ ).

\section{Results and Discussion}

The respiration rate of control broccoli decreased and then increased slightly during the 18 -d posttreatment period at $10{ }^{\circ} \mathrm{C}$ (Fig. 1A). Treatment with MCP followed by storage in air reduced the respiration rate throughout the 18-d investigation period, while ethylene increased the respiration rate of nontreated broccoli. The 12-h MCP treatment prior to exposure to ethylene eliminated the ethylene-induced respiration rise, and also reduced the respiration rate to a level similar to MCP-treated broccoli stored in ethylenefree air.

Larger hue angle values (greener appearance) are highly correlated with total chlorophyll content of broccoli florets (Tian et al., 1994). In our study, hue angle of control broccoli did not change within the first $8 \mathrm{~d}$ (Fig. 1B), but decreased rapidly thereafter. Continuous ethylene accelerated yellowing. Treatment with MCP, even when followed by continuous exposure to ethylene, prevented yellowing over the entire 18-d period. Chroma of control broccoli changed little during the first $8 \mathrm{~d}$ at $10{ }^{\circ} \mathrm{C}$ (Fig. 1C), then gradually increased from 12-18 d. Continuous ethylene exposure resulted in increased chroma. Treatment with MCP, with or without ethylene, prevented yellowing. These results suggest that yellowing of broccoli is mediated through ethylene action.

The effect of MCP on inhibiting the effect of ethylene on respiration rates was dosedependent (Fig. 2A). Respiration rates were similar for 0.01 and $0.1 \mu \mathrm{L} \cdot \mathrm{L}^{-1} \mathrm{MCP}$ treatments. A concentration of $1 \mu \mathrm{L} \cdot \mathrm{L}^{-1}$ was most effective but as little as $0.01 \mu \mathrm{L} \cdot \mathrm{L}^{-1}$ inhibited the ethylene-promoted decrease in hue angle 


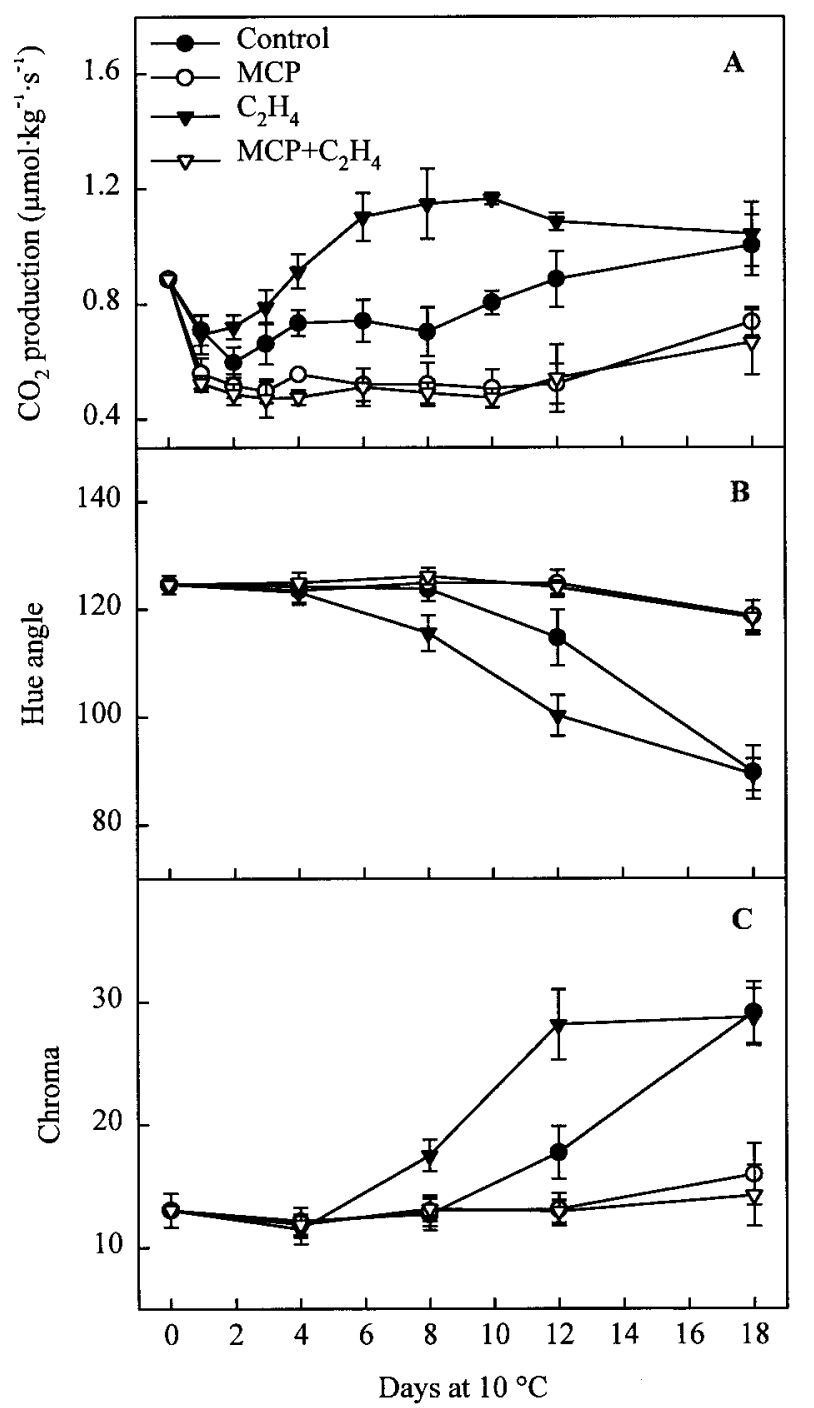

Fig. 1. Interactive effect of ethylene and $\mathrm{MCP}$ on $(\mathbf{A})$ respiration rate, $(\mathbf{B})$ hue angle, and $(\mathbf{C})$ chroma of 'Windsor' broccoli stored at $10^{\circ} \mathrm{C}$. The broccoli was treated with air (control), $12 \mathrm{~h} 1 \mu \mathrm{L} \cdot \mathrm{L}^{-1} \mathrm{MCP}(\mathrm{MCP}), 1 \mu \mathrm{L} \cdot \mathrm{L}^{-1}$ continuous ethylene $\left(\mathrm{C}_{2} \mathrm{H}_{4}\right)$, or $12 \mathrm{~h} 1 \mu \mathrm{L} \cdot \mathrm{L}^{-1} \mathrm{MCP}$ followed by $1 \mu \mathrm{L} \cdot \mathrm{L}^{-1}$ continuous ethylene treatment $\left(\mathrm{MCP}+\mathrm{C}_{2} \mathrm{H}_{4}\right)$. Vertical bars represent SD of means, $\mathrm{n}=5$.

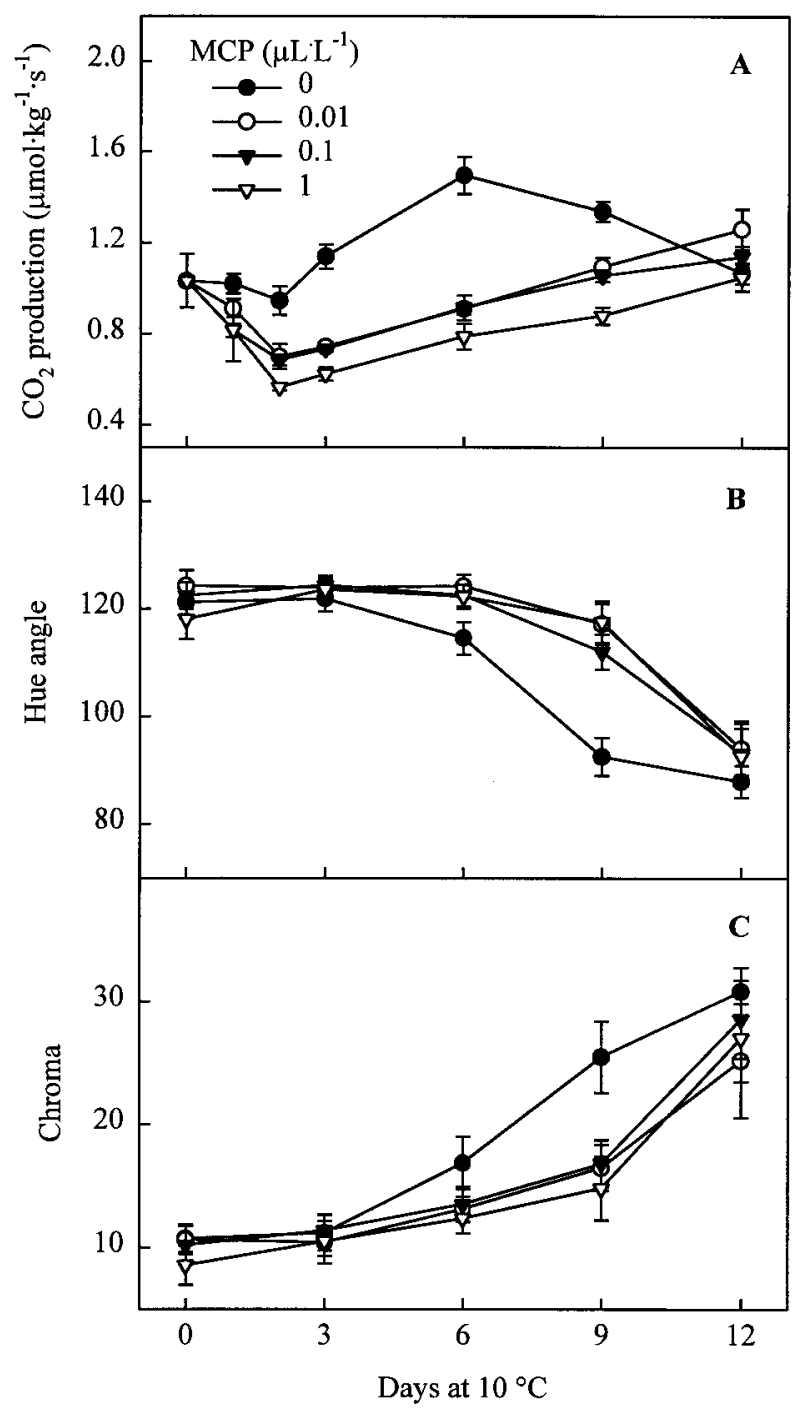

Fig. 2. Effect of MCP concentration on (A) respiration rate, (B) hue angle, and $(\mathbf{C})$ chroma of 'Windsor' broccoli stored at $10{ }^{\circ} \mathrm{C}$. The broccoli was treated with $0,0.01,0.1$, or $1 \mu \mathrm{L} \cdot \mathrm{L}^{-1} \mathrm{MCP}$ for $12 \mathrm{~h}$ prior to continuous exposure to $1 \mu \mathrm{L} \cdot \mathrm{L}^{-1}$ ethylene. Vertical bars represent SD of means, $\mathrm{n}=5$. and increase in chroma (Fig. $2 \mathrm{~B}$ and C). The $0.01,0.1$, and $1 \mu \mathrm{L} \cdot \mathrm{L}^{-1} \mathrm{MCP}$ treatments were equally effective in delaying yellowing or loss of chroma. The lack of a dose response for color change contrasts with the report of $\mathrm{Ku}$ and Wills (1999) and may be due to our use of a different cultivar, longer treatment duration, or treatment at $10^{\circ} \mathrm{C}$. In contrast with the results of the previous experiment, broccoli treated with MCP, then exposed to $1 \mu \mathrm{L} \cdot \mathrm{L}^{-1}$ ethylene, yellowed between 9 and $12 \mathrm{~d}$ after treatment. Broccoli used in the concentration experiment had been stored at $0{ }^{\circ} \mathrm{C}$ for $25 \mathrm{~d}$ prior to treatment. This length of storage may make broccoli more susceptible to yellowing (Tian et al., 1994).

Makhlouf et al. (1989) proposed that broccoli is climacteric because respiration rate and ethylene production increase during senescence as florets become yellow. In our experiments, respiration increased slightly during the yellowing of florets (days 8 to 18 , Fig. 1), and exposure to ethylene promoted the rise in respiration. The MCP treatment reduced the respiration rate compared to controls and inhibited the ethylene-induced increase in respiration rate. These results support the view that broccoli is climacteric.

Our results are in agreement with earlier findings that broccoli is sensitive to exogenous ethylene (Ku and Wills, 1999; Tian et al., 1994). The first $2 \mathrm{~d}$ of ethylene treatment did not increase yellowing. Tian et al. (1994) suggested that broccoli tissues are less sensitive to ethylene during this time. The respiration rate fell within $24 \mathrm{~h}$ after MCP treatment, suggesting that ethylene could be perceived continuously. The metabolic processes that result in yellowing may need to progress for at least $2 \mathrm{~d}$ for enough color change to occur to be detected by the chromameter used in this study.
Treatment with MCP effectively inhibits respiration and yellowing of broccoli at concentrations as low as $0.01 \mu \mathrm{L} \cdot \mathrm{L}^{-1}$, even in the presence of $1 \mu \mathrm{L} \cdot \mathrm{L}^{-1}$ ethylene. This indicates that: 1) increases in respiration and yellowing occurring during broccoli senescence are mediated by ethylene action; and 2) ethyleneinduced increases in respiration and yellowing occur via a similar signaling pathway, because MCP treatment inhibits both of these responses. The use of MCP can delay the yellowing of broccoli even in the presence of ethylene. Broccoli stored at $0{ }^{\circ} \mathrm{C}$ can be held for 2 weeks; however, higher temperatures are often encountered during handling, transportation, and retail marketing.

The use of MCP can reduce the requirement for low temperature while still prolonging storage life; therefore commercial use of MCP may enhance broccoli condition under suboptimal postharvest conditions. Should 
MCP become available for commercial use, broccoli losses due to poor control of temperature during wholesale and retail handling should be greatly reduced.

\section{Literature Cited}

Abdi, N., W.B. McGlasson, P. Holford, M. Williams, and Y. Mizrahi. 1998. Response of climacteric and suppressed-climacteric plums to treatment with propylene and 1-methylcylcopropene. Postharvest Biol. Technol. 14:29-39.

Borochov, A. and W.R. Woodson. 1989. Physiology and biochemistry of flower petal senescence. Hort. Rev. 11:15-43.

Bastrash, S., J. Makhlouf, F. Castaigne, and C. Willemot. 1993. Optimal controlled atmosphere conditions for storage of broccoli florets. J. Food Sci. 58:338-360.

Batal, K.M., E.K. Heaton, D.M. Granberry, and L.R. Beuchat. 1982. Effects of $\mathrm{N}^{6}$-benzyladenine and storage temperature on shelf-life and quality of raw and cooked broccoli (Brassica oleracea L. var. italica). J. Food Sci. 47:1675-1678.

Brennan, P.S. and R.L. Shewfelt. 1989. Effect of cooling delay at harvest on broccoli quality during postharvest storage. J. Food Quality $12: 13-22$
Fan, X. and J.P. Mattheis. 1999. Methyl jasmonate promotes degreening of apple fruit independent of ethylene action. HortScience 34:310 312.

Forney, C.F., J.P. Mattheis, and R.K. Austin. 1991. Volatile compounds produced by broccoli under anaerobic conditions. J. Agr. Food Chem. 39:2257-2259.

Golding, J.B., D. Shearer, S.G. Wyllie, and W.B. McGlasson. 1998. Application of 1-MCP and propylene to identify ethylene-dependent ripening processes in mature banana fruit. Postharvest Biol. Technol. 14:87-98.

Gillies, S.L and P.M.A. Toivonen. 1995. Cooling method influences the postharvest quality of broccoli. HortScience 30:313-315.

Hardenburg, R.E., A.E. Watada, and C.Y. Wang. The commercial storage of fruits, vegetables, and florist and nursery stocks. U.S. Dept. Agr. Agr. Hdbk. No. 66.

Izumi, H., A.E. Watada, and W. Douglas. 1996. Optimum $\mathrm{O}_{2}$ or $\mathrm{CO}_{2}$ atmosphere for storing broccoli florets at various temperatures. J. Amer. Soc. Hort. Sci. 121:127-131.

Ku, V.V.V. and R.B.H. Wills. 1999. Effect of 1-methylcyclopropene on the storage life of broccoli. Postharvest Biol. Technol. 17:127132.

Makhlouf, J., C. Willemot, J. Arul, F. Castaigne, and J. Emond. 1989. Regulation of ethylene biosynthesis in broccoli flower buds in con- trolled atmospheres. J. Amer. Soc. Hort. Sci. 114:955-958.

Ryall, A.L. and W.J. Lipton. 1979. Handling, transportation and storage of fruits and vegetables. vol. 1. Vegetables and melons. 2d ed. AVI, Westport, Conn.

Serek, M., E.C. Sisler, and M.S. Reid. 1994. A volatile ethylene inhibitor improves the postharvest life of potted roses. J. Amer. Soc. Hort. Sci. 119:572-577.

Sisler, E.C. and M. Serek. 1997. Inhibitors of ethylene responses in plants at the receptor level: Recent developments. Physiol. Plant. 100:577-582.

Sisler, E.C., M. Serek, and E. Dupille. 1996. Comparison of cyclopropene, 1-methylcyclopropene, and 3,3-dimethylcyclopropene as ethylene antagonists in plants. Plant Growth Regulat. 18:169-174.

Tian, M.S., C.G. Downs, R.E. Lill, and G.A. King. 1994. A role for ethylene in the yellowing of broccoli after harvest. J. Amer. Soc. Hort. Sci. 119:276-281.

Wang, C.Y. 1977. Effect of aminoethoxy analog of rhizobitoxine and sodium benzoate on senescence of broccoli. HortScience 12:54-56.

Yamaguchi, N. and A.E. Watada. 1998. Chlorophyll and xanthophyll changes in broccoli florets stored under elevated $\mathrm{CO}_{2}$ or ethylenecontaining atmosphere. HortScience 33:114117. 